\title{
Forgiveness, Humility, and Hope: An Interview With Everett L. Worthington Jr.
}

Jesse Fox

jfox1@loyola.edu

Patrick R. Mullen

College of William and Mary, prmullen@wm.edu

Amanda Giordano

Follow this and additional works at: https://scholarworks.wm.edu/aspubs

\section{Recommended Citation}

Fox, Jesse; Mullen, Patrick R.; and Giordano, Amanda, Forgiveness, Humility, and Hope: An Interview With Everett L. Worthington Jr. (2017). COUNSELING AND VALUES, 62(1).

10.1002/cvj. 12046

This Other is brought to you for free and open access by the Arts and Sciences at W\&M ScholarWorks. It has been accepted for inclusion in Arts \& Sciences Articles by an authorized administrator of W\&M ScholarWorks. For more information, please contact scholarworks@wm.edu. 


\title{
Perspective Interview Series
}

\section{Forgiveness, Humility, and Hope: An Interview With Everett L. Worthington Jr.}

\begin{abstract}
Jesse Fox, Patrick R. Mullen, and Amanda Giordano
In this article, the authors interviewed Everett L. Worthington Jr. regarding his impact on research related to forgiveness, humility, and hope. They briefly highlight Worthington's professional career, provide the transcription of a detailed interview, and offer a list of suggested readings on the topics discussed in this interview. The authors' aim is to highlight Worthington's scholarly works, driving motivation, and thoughts on future research and to provide resources for working with forgiveness, humility, and hope with clients.
\end{abstract}

Keywords: Everett L. Worthington Jr., forgiveness, hope, humility

verett L. Worthington Jr. is a professor of psychology at Virginia Commonwealth University (VCU) in Richmond, Virginia, a position he has held for 38 years. He is a prolific scholar in the field of positive psychology with 26 authored books, seven edited books, and more than 400 articles and book chapters. In addition, Worthington has held numerous visiting scholar positions over his tenure at prestigious universities across the globe, including St. Edmund's College at the University of Cambridge in 2010. He was also recognized by the Association for Spiritual, Ethical, and Religious Values in Counseling in 1991 for his scholarly contribution to the Counseling and Values journal by receiving the Donald Biggs-Gerald Pine Award for Outstanding Scholarly Contribution for his article "Marriage Counseling: A Christian Approach to Counseling Couples." In light of these and other accomplishments, it is evident that Worthington's influence in the field of counseling is widespread.

Worthington has spent a lifetime devoted to his personal mission, which he succinctly described as "to do all I can to promote forgiveness in every

Jesse Fox, Department of Pastoral Counseling, Loyola University Maryland; Patrick R. Mullen, Department of School Psychology and Counselor Education, College of William \& Mary; Amanda Giordano, Department of Counseling and Higher Education, University of North Texas. Correspondence concerning this article should be addressed to Jesse Fox, Department of Pastoral Counseling, Loyola University Maryland, 8890 McGaw Road, Columbia, MD 21045 (e-mail: jfox1@loyola.edu).

(C) 2017 by the American Counseling Association. All rights reserved. 
willing heart, home, and homeland." If his scholarship is any indication of his fulfillment of that mission, there is little doubt that he has succeeded (he has published more than 100 articles on the topic of forgiveness alone). A centerpiece of Worthington's work in the area of forgiveness is his development of the REACH model. REACH is an acronym for a forgiveness intervention: Recall the hurt, Empathize with your partner (try to understand the perspective of the person who hurt you), Altruistic gift (give the unselfish gift of forgiveness to the person who hurt you), Commit (make a public commitment to forgive the person who hurt you), and Hold onto forgiveness (without forgetting the hurt, stay true to your commitment to forgive; Worthington, 2003). Adaptations of the model are appropriate for both secular (Worthington, 2006) and Christian audiences (Worthington, 2010). Also, the model can be implemented in a 6-hour psychoeducational group format, and, to date, 22 empirical studies support the efficacy of the model in treatment (Wade, Hoyt, Kidwell, \& Worthington, 2014; Worthington \& Sandage, 2015). Worthington identified two experiences that motivated his study of forgiveness: (a) his work as a couples and family counselor in which he taught clients the important skill of forgiveness and (b) his own personal journey confronting his own pain after the murder of his mother and subsequent suicide of his brother. Thus, Worthington is one of those rare individuals who has the capacity to truly bridge research and practice with sacred and secular voices to better understand the ultimate concerns of the collective human condition.

In addition, Worthington is known for his work in the field of couples counseling, including, most recently, his research on humility and his role in empirically substantiating the positive effect of spiritual and religious interventions in counseling. In 2014, Ripley and Worthington published a book titled Couple Therapy: A New Hope-Focused Approach, which details a unique approach to couples counseling that they codeveloped. The hope-focused approach is one of only four couples counseling models that meets the rigorous standards to be considered an evidence-based practice in psychology (Jakubowski, Milne, Brunner, \& Miller, 2004). Worthington's work in the field of humility is the most recent wave of his scholarly pursuits, and he is one of the first investigators to publish an intervention study on the topic (Davis et al., 2013). In addition, he works closely with the funded projects of the John Templeton Foundation to scientifically explore character virtues. Moreover, in a major contribution to the field of spirituality and religion in counseling, Worthington, Hook, Davis, and McDaniel (2011) coauthored a meta-analysis of spiritual and religious interventions in counseling, which is featured in Norcross' edited volume Psychotherapy Relationships That Work. The findings of this meta-analysis attested to the added benefits of spiritual and religious interventions over and above secular-based approaches (Worthington et al., 2011). Therefore, along with developing models of forgiveness and couples counseling, Worthington also has provided much-needed empirical support for religious and spiritual interventions in counseling. 
In April 2016, the first and second authors interviewed Worthington to better understand his impressive accomplishments. We sought to explore his work from multiple perspectives based on our line of inquiry. First, we explored the early influences that inspired his life's professional work. Next, we inquired about his current scholarly endeavors, his personal views on present trends in counseling, and his perspective on needs for future development. Then, we asked how he contextualizes forgiveness, hope, and humility within the larger scope of spirituality and religion. Finally, we asked Worthington to provide a list of essential resources for counselors who want to learn more about these subjects as they relate to their clinical practice (see Appendix). The subsequent sections are an edited transcript of our interview with Worthington.

\section{Early Influences and Current Challenges}

Interviewers (INTs): Please describe some of your earliest influences (e.g., people, events, circumstances) regarding your career as a scholar.

Everett L. Worthington Jr. (ELW): I came out of a lower socioeconomic class background, and one of the few people I knew who had gone to college was my uncle, who was a personnel manager at Indiana University. When I was in the eighth grade, my uncle taught me how to play chess and introduced me to the idea that there was more to growing up than just working in labor, which is kind of what we had seen all of our lives. I took off for college as one of the few people in my high school attending college, and I majored in nuclear engineering. I got my degree from the University of Tennessee in 1968, and during my time there I had the chance to work with a faculty member in nuclear engineering who really introduced me to the idea of research, Tom Kerlin. Then, I went to Massachusetts Institute of Technology on an Atomic Energy Commission Special Fellowship, got a master's degree, and did a master's project there under the direction of two people: one was a nuclear engineer, Ed Mason, who was really famous in nuclear engineering, and the other was Paul MacAvoy, an economist studying energy policy, who just recently died. Paul was an energy adviser for President Carter. These two men nurtured me along in doing a master's thesis and introduced me to scholarship for the first time. Pretty much, I learned that, well, I did not want to do scholarship in nuclear engineering. So it was an important learning experience for me.

Shortly after, I went in to the Navy and taught nuclear physics. While there, I helped write a textbook on nuclear physics for training enlisted personnel, and I was a senior division officer with the privilege of directing 11 officers and five chiefs along with over 200 enlisted personnel. Basically, serving as a senior author of the textbook and helping out the people under my command gave me a feeling of productivity. 
Then I went to the University of Missouri-Columbia, and got into its counseling psychology program. I worked with Bob Dolliver, who was a great mentor in that I was, no doubt, an independent thorn in his flesh. Yet Bob was very generous and he gave me a lot of freedom to work on research. Bob talked with me about research and didn't try to guide me a lot, but was much more of a facilitator and encourager. I think my experience with Bob was a model for how to engage somebody in the intellectual life and how to show them that ideas can be a lot of fun. Working with Bob was a real formative experience for me as he mentored me in psychological research. When I came to VCU, I was working on something in which Bob didn't have any interest. Bob was in career psychology, and although I did another paper or two and some practice in that area, I was focused on topics such as cognitive behavioral self-control of pain, stress, anxiety, and depression. So, Bob Dolliver, Ed Mason, and Paul MacAvoy planted the seeds for me.

INTs: How did those early training experiences become a part of what you subsequently became known for, in terms of your research on forgiveness?

ELW: Those experiences didn't really guide me toward studying forgiveness. It was more my practice that actually guided me there. At the University of Missouri, I became interested in couples counseling and gravitated toward counseling couples instead of individuals and families. During my prelicensure years, when I was accumulating clinical hours, most of them were in couples counseling. In my experience, you can't see couples without realizing that forgiveness is a major issue that most of them deal with, and want to deal with. So, that really was what drove me to the content of studying forgiveness. I didn't start doing research on it until Mike McCullough came to me as a beginning graduate student in 1990. Mike has become a wonderful psychologist who has far outshone my accomplishments. It is nice to have been his initial mentor.

Mike was really interested in studying forgiveness, which no one was studying at that time except Robert Enright at the University of Wisconsin. Mike would go to the library (this was back when you had to go to the library in order to access research) and come back with an article on forgiveness and we would have our weekly research meeting. I would sit back and stroke my beard in a wise way as he told me about the article, but [I] didn't know anything about what he was saying! After we finished, I would run over to the library stacks and drag that book off the shelf and read the article so that I could keep up with this really bright graduate student. Shortly after Mike started on that route, Steve Sandage, who is now an endowed professor at Boston University in the Danielsen Institute, became interested in studying forgiveness. So then I started having two meetings a week in which I didn't know what we were talking about! Furthermore, I was spending twice as much time over in the library reading articles on forgiveness. That is how our research on forgiveness started. 
Additionally, there's an interesting little anecdote, if you'll permit me to tell it. In 1996, my mother was murdered in a home invasion. That really threw me for a loop, and for the subsequent months, I was struggling with what was important in life-that kind of existential-type questions. Later that year, I was invited to go to South Africa and was appointed by the South African government as a visiting scholar on their behalf. As I got on the plane to fly to South Africa, I sat beside a man who was a multinational, multicontinent chief executive officer. I asked him about the secret of his success. He said, "It's very simple. I am able to make good decisions about what our company should pursue and what we should not pursue." I asked him how he made those decisions, and he replied, "I just ask people, 'How is this new idea of yours going to make us number one or number two in the world?'" I asked why it is important to be number one or number two; after all, it is a big world. He answered by asking me to name the number one soft drink in the world. I said Coke. He then asked me to name the number two soft drink in the world. I said Pepsi. He asked me to name the third. I sat in stunned silence. He said, "Aha! That's my point. There's kind of a market law that whoever's number one in the world gets about two thirds of the market and whoever's number two gets about $25 \%$ of the market, which is $92 \%$ of the market. That means those in third through 50th place get to divide up only a remaining $8 \%$. I am not going to support ideas other than those that make us number one or two in the world." Well, of course, I was sitting there on the plane narcissistically thinking of my own research career and asking myself if I was number one or two in anything. At that point, my mission statement was all about marriage counseling, and I could think of person after person after person who already was eminent in marriage counseling. I realized I was probably number 50 or 60 . Then it dawned on me that there were only two groups doing research on forgiveness. Well, that made me at least number two! So I thought that there was nothing to lose. Over the course of the next year or so, I formulated a mission statement that has remained since then. My mission is to do all I can to promote forgiveness in every willing heart, home, and homeland. Coming out of that little interaction amid a period when forgiveness was a very personal thing for me, after my mom's murder, changed things. Studying forgiveness and all that is associated with it became the driving force in my professional career and personal life too.

\section{INTs: What are the current influences that are part of your work today?}

ELW: Over the course of preparing for an imminent retirement, my students move through the pipeline and I'm able to collaborate with many brilliant students I've had in the past. I continue to be involved in the research that we've forged together. My ability to collect data ends with my current group; the last two students are about ready to leave at the end of this semester. That will basically collapse my data-gathering capability, so it's led me to think more about how can I continue to be involved in scholarship and contribute to the 
good of humanity without being able to follow my own ideas as directly as I could when I was collaborating with students.

I have always told students that research is all about collaboration, and I never tried to impose my ideas on them. Instead, I tried to say, "I'm interested in forgiveness. I'm interested in couples. And I'm interested in religion/spirituality. What are you interested in? Let's look at the intersection." Without having new graduate students, that conversation isn't going to take place after this year. It's going to be more working as a collaborator with former students and the people whom I've interacted with over the years. That life change has certainly made a big influence on what I do today. Now I think more about using secondary sources, like using the research that other people have done and trying to make sense of it through review papers and books. It's a change, like mental gymnastics.

\section{Researching Humility}

INTs: What led you to pursue your current research on humility?

ELW: I got interested in humility because I was interested in virtue. Positive psychology is mostly thought of as a character strength or virtue, and humility seemed like it was a very important virtue. One problem with studying humility scientifically, however, is knowing when a self-report might be accurate and when it might not be. If I asked someone, "Are you humble on a scale of 0 to 10, , and they say, "10," I don't know if that's correct. I don't know whether their self-report is an accurate self-portrayal or a narcissistic projection. June Tangney at George Mason [University] called into question the validity of self-reports of humility. She wrote a paper in the Journal of Social and Clinical Psychology in 2000 that, by raising the excellent question about validity of selfreported humility, paralyzed much of the study of humility. By 2007, I thought I could write a book on humility, so I submitted a proposal to the Templeton Press. They said they loved my proposal, but they had given someone else a contract to write a book on humility 2 weeks prior. I said, "Oh well. That's life in a big city!" and I put the idea aside.

Then, about 6 months later, I got a phone call from Templeton Press. They said the person that they had contracted with to write the book on humility had to pull out, and they asked whether I was still interested. I told them I was. They said, good, it was due in a month. So I wrote the book in a month. It was a small book, but it presented the idea that we may not be able to validly report on our own humility, but others can. I organized that book around people I called my heroes of humility. After writing that book, then graduate student Donnie Davis, now at Georgia State [University], got interested in studying humility scientifically. We joined with Joshua Hook, now at the University of North Texas in counseling psychology, and Darrell Van Tongeren, who is a social psychologist now at Hope University, to put together different ways of studying and measuring humility. Specifically, we have been using reports from others, validating self-reports against reports 
from others, and exploring behavioral measures. Recently, Donnie, Josh, and I completed editing the chapters for a book called Handbook of Humility (Worthington, in press) to be published by Routledge. That has been a very fruitful collaboration.

INTs: Did any facts or figures about humility come as a surprise?

ELW: When I started to study forgiveness, we were on the ground floor right after Bob Enright and Mike McCullough, who were very productive. Then the Templeton Foundation funded a campaign for forgiveness research and asked me to be the executive director. That experience ended up funding a lot of grants and the number of publications on forgiveness grew exponentially; it went from 58 publications in 1997 to over 1,100 in 2005, and then to 2,000 publications in 2010. In a parallel way, humility attracted some initial attention from funding agencies such as the Templeton Foundation. Therefore, I expected that the humility literature would grow exponentially just like the forgiveness literature.

It turned out the story was more humble. The growth in humility research was linear, almost a straight line increase, instead of an exponential increase. Sometimes I ask myself about the difference between humility and forgiveness research, and I think the answer lies in the fact that forgiveness has a lot of personal relevance. When I would tell someone I was studying forgiveness, they would almost always say, "That's great, we really should be studying forgiveness. I've got this grudge I've held for years and it makes me feel sick-like my heart's going to explode." People recognize physical, mental, social, and spiritual repercussions from unforgiveness. With humility, however, people don't say, "I have this arrogance and narcissism and it's really bothering me!" Rather, they say, "I like humble people who really care about me (socially)." And they often think, I want to be a person like that. The motivators for humility are not as much about self-interest (as with forgiveness) as about social attractors.

\section{Scholarly Legacy}

INTs: How do you think your work has influenced the field?

ELW: In terms of forgiveness, I think I was in a very privileged place being asked by the Templeton Foundation to serve as the executive director of the forgiveness research campaign. The Templeton Foundation didn't fund my research in that campaign, but that experience allowed me to participate in raising $\$ 6.4$ million above and beyond the $\$ 3$ million the foundation initially gave toward studying forgiveness. That fund-raising ended up funding over 30 researchers' initial work on forgiveness. I was in a position that was very blessed in terms of being able to facilitate the work of a lot of people that started a new field. I also have been really blessed in terms of being able to work with my graduate student colleagues and see them develop as major researchers themselves. I can't take credit 
for their brilliance and performance. I usually say my mentoring style is aim them and get out of the way and don't inhibit them. However, I think having the chance to get them started and then watching them develop themselves has had a multiplying effect on the field, too. My influence has been to facilitate other people, and collectively, we end up having what I narcissistically think might eventually be a big impact on the field of positive psychology.

INTs: Building off that, what do you think is the most significant contribution you've made over the course of your career?

ELW: I think I've been involved in writing a number of theoretical pieces that have advanced our understanding of forgiveness - differentiating between making a decision to forgive and emotionally forgiving, recognizing that people deal with unforgiveness and injustice in many ways, with forgiveness being just one of them, contributing to the understanding of the relationship between religion and forgiveness, and developing the REACH forgiveness intervention that seems to have gotten a fair amount of traction. There's probably been about 25 randomized clinical trials in the REACH forgiveness model, which is about the same number as with Bob Enright's (2001) Process Model of Forgiveness. The very gratifying thing is the sheer number of people who practice helping patients and clients forgive clinically. I make resources available at no cost on my website (www.evworthington-forgiveness.com). There are do-it-yourself workbooks, leader manuals for groups, participant manuals, and protocols for helping couples among others that are free to the public. I even give people no-cost training tapes in a Christian version and a secular version of the REACH forgiveness group model that has influenced practice as much as it's influenced the clinical research of forgiveness. I would say when I hang up my official spurs in a couple of years, these resources are probably what I will look back on as my contribution, in addition to the wonderful colleagues I have been able to work with.

INTs: What does it mean to you to have made this contribution?

ELW: I have struggled with forgiveness in my own life, including forgiving myself when my brother committed suicide. I felt like I failed him in a number of ways. So I realize, personally, how much pain can be alleviated by forgiveness. To know that a lot of people are using the $\mathrm{REACH}$ forgiveness model means there is a lot less pain in the world than there would be otherwise. One of my friends and his family went to Kansas to be with his ailing mother during her last days. They went to a church, saw the pyramid of the five steps of the REACH forgiveness model on a screen, and a picture of me beside it. My friend said, "Wow, I can't get away from that guy! Virginia to Kansas and there he is!" It was very gratifying to know that there is a little rural community church in Kansas using this model to help people in their congregation to be able to forgive. 


\section{Unexplored Questions}

INTs: What questions are left unexplored about humility, forgiveness, and hope?

ELW: I think humility is the exciting area right now just because it's newer and so the fruit are lower hanging and easily grasped. There are only a few intervention studies on humility. We were fortunate to publish the first one, but there are a lot of people who value humility and want to be more humble, so more studies are needed. I just wrote a chapter for the Handbook of Humility (Worthington, in press) on political humility. Usually, the response to that is "I thought that was an oxymoron!" Certainly, the 2015-2016 election cycle has demonstrated that perhaps, as a nation, we could use a little more political humility. I just got back from a conference in Istanbul, 2 hours before a bomb went off in Taksim Square. The conference was about religion, spirituality, counseling, and care. It was a wonderful example of religious intellectual humility in which people were able to share different committed ideas without compromise but in a civil way. So, I would say that political humility, intellectual humility, and religious humility are other unexplored areas besides interventions.

\section{Forgiveness, Hope, and Humility Within Spirituality and Religion}

INTs: How does forgiveness and hope fit within the context of spirituality and religion?

ELW: Forgiveness, in particular, is valued by every major religion, and about $95 \%$ of all people worldwide claim to be religious. Peter Berger, a sociologist who studies religion and spirituality worldwide, says most people believe that religion and spirituality are integrated and most people are religious. Many in our profession think more about spirituality than they do religion, but globally, that is a minority view. Most religions facilitate hope by providing meaning, purpose, and a sense that there is more than just this present life. Spirituality does this too. Spirituality involves one's closeness or connection with what he or she believes to be sacred. We all have this sense of spirituality. When we fall short and transgress against what we hold to be sacred, we need forgiveness. For example, if I were secular and held humanity sacred, yet I hurt other people, then I would have transgressed against the sacred and ruptured my connection and closeness to it. I would then be in need of something that would help repair that emotional bond. Forgiveness is one of those things. Hope, of course, refers to something that I'm looking forward to-the restoration of those bonds. Thus, forgiveness and hope fit in both religious and nonreligious types of spirituality and certainly in religion itself.

INTs: Would you place humility in the context of religion and spirituality too?

ELW: Well, I do, because in my definition of humility, people have an accurate view of themselves and a spirit of being teachable, meaning they 
can learn from other people and other things (like the sacred). The second quality of humility is that the individual has a modest presentation of herself or himself. The third quality is that they are other-oriented in a way that exhibits power under control to lift people up instead of squash them down. So, I think that humility is spiritual in that its other-orientedness is all about connection and closeness with people.

\section{Incorporating Forgiveness and Hope Into Clinical Work}

INTs: What can counselors do to integrate forgiveness and hope into their practice with clients?

ELW: Back in the early 1960s, Jerome Frank said that hope is something that counselors do for clients; [they] provide and promote hope. That is a common factor associated with any type of psychotherapeutic activity. Additionally, people have forgiveness issues because we live in an interpersonal world and people just get hurt. Most clients have issues in forgiveness. However, most counselors cannot spend a lot of time dealing with forgiveness because "unforgiveness" is not in the DSM [Diagnostic and Statistical Manual of Mental Disorders; 5th ed.; American Psychiatric Association, 2013], but it is very important and has physical, mental, relational, and often spiritual consequences.

A practical way that people can integrate forgiveness into their clinical work is to run a psychoeducational forgiveness group as an adjunct to a practice. If a counselor is in a group practice with three or four other people, they could recruit clients and offer a 6-hour forgiveness group on a Saturday. If the group ran at a relatively inexpensive rate, then it has the potential to touch a lot of people. We did a meta-analysis on forgiveness interventions and found that you get about a one tenth of a standard deviation of change in forgiveness for every hour people spend working on it. Here's the beautiful part. Let's take a 6-hour Saturday psychoeducational group. You also get about three tenths of a standard deviation of change in depression and a three tenths of a standard deviation change in anxiety and about a sixth tenths standard deviation change in hope during that group experience! And depression and anxiety are not even mentioned. You could potentially give an adjunctive psychoeducational 6-hour intervention on forgiveness and, in turn, increase forgiveness and improve mental health in a very measurable way. To put that in perspective, 26 weeks of CBT [cognitive behavior therapy] get clients about 1.2 [standard deviations] of change. So, the little 6-hour psychoeducational group on forgiveness not only helps people forgive but [also] gets about one third of the gains that they will achieve in all of psychotherapy aimed at depression and anxiety.

INTs: How could you tell or observe that a counselor is integrating forgiveness and hope into their work with clients? 
ELW: I think clients will talk about unforgiveness in a straightforward way. Clients will talk about how much unforgiveness has been bothering them. They will say they feel eaten up with anger, resentment, or bitterness. Therefore, it's easy to see when someone needs to address forgiveness. Often, though, clients may wonder if forgiveness is religious. It turns out it's not. Forgiveness is indeed valued by religion, but it's also valued in secular settings. Counselors can have an influence on a client's unforgiveness by addressing it directly in therapy. But, since 1 hour of therapy results only in about one tenth of a standard deviation of change, clients have to do something other than just dealing with unforgiveness in a psychotherapy session. For this reason, we developed the Do It Yourself workbooks online at no cost (www.evworthington-forgiveness.com/diy-workbooks). There's a workbook for humility, forgiveness of others, and forgiveness of self so that the counselor doesn't have to solve a person's forgiveness problem in the session. People who work through those 7-hour workbooks get seven tenths of a standard deviation of change in forgiveness, and commensurate changes in depression (i.e., 0.35 [standard deviations]), anxiety (i.e., 0.35 [standard deviations]), and hope (i.e., 0.70 [standard deviations]). The availability of these free workbooks is good news to clients, and they can really empower the counselor to be able to turn them on to a free resource that is empirically supported with several studies.

INTs: Have you encountered any drawbacks in your work in these areas?

ELW: When people think of humility, they may think it means being satisfied with doing the right thing even if it means never receiving the promotion they would love to have. Humility can be misunderstood and thought to mean that you don't ever stand up for what you believe, but that's not humility. Humility means having an accurate view of yourself and using power under control, not to intimidate people, but to lift people up and not to squash them down. So, I think as people rightly understand humility, you can minimize the negative consequences such as predators who take advantage of anyone who forgives or is humble. I think humility is having a core that's very solid; in a way, it's like an avocado-it has a soft and tasty external layer, but it has a hard core. It's not easy to be humble and it's not easy to forgive. It's hard, actually. But that's the virtuous core. If we as counselors can promote those kind of virtues, we make the world a better place-not only because we've helped people heal but [also] because we've helped them to be better people.

\section{Closing Remarks}

Worthington's life and work are in seamless unity. What he has studied as a scholar grew out of his experiences, some of which were exceedingly painful, and which he now uses to help and transform the lives of others. What is hard to convey in a written interview is how it is evident that Worthington 
has embodied the virtues he describes as his life's work. We are grateful for the opportunity to speak directly with him and reflect on his contributions to the counseling field, which have already changed many lives and will likely continue to do so for several generations.

\section{References}

American Psychiatric Association. (2013). Diagnostic statistical manual of mental disorders (5th ed.). Arlington, VA: Author.

Davis, D. E., Worthington, E. L., Jr., Hook, J. N., Emmons, R. A., Hill, P. C., Bollinger, R. A., \& Van Tongeren, D. R. (2013). Humility and the development and repair of social bonds: Two longitudinal studies. Self and Identity, 12, 58-77. doi:10.1080/15298868.2011.636509

Enright, R. D. (2001). Forgiveness is a choice: A step-by-step process for resolving anger and restoring hope. Washington, DC: American Psychological Association.

Jakubowski, S. F., Milne, E. P., Brunner, H., \& Miller, R. B. (2004). A review of empirically supported marital enrichment programs. Family Relations, 53, 528-536. doi:10.1111/j.0197-6664.2004.00062

Ripley, J. S., \& Worthington, E. L., Jr. (2014). Couple therapy: A new hope-focused approach. Downers Grove, IL: InterVarsity Press.

Tangney, J. P. (2000). Humility: Theoretical perspectives, empirical findings and directions for future research. Journal of Social and Clinical Psychology, 19, 70-82. doi:10.1521/jscp.2000.19.1.70

Wade, N. G., Hoyt, W. T., Kidwell, J. E. M., \& Worthington, E. L. (2014). Efficacy of psychotherapeutic interventions to promote forgiveness: A meta-analysis. Journal of Consulting and Clinical Psychology, 82, 154-170. doi:10.1037/a0035268

Worthington, E. L., Jr. (2003). Forgiving and reconciliation: Bridges to wholeness and hope. Downers Grove, IL: InterVarsity Press.

Worthington, E. L., Jr. (2006). The path to forgiveness: Six practical sessions for becoming a more forgiving person. Richmond, VA: Author.

Worthington, E. L., Jr. (2010). Experiencing forgiveness: Six practical sessions for becoming a more forgiving Christian. Richmond, VA: Author.

Worthington, E. L., Jr. (in press). Political humility: A post-modern reconceptualization. In E. L. Worthington Jr., D. E. Davis, \& J. N. Hook (Eds.), Handbook of humility: Theory, research, and applications. New York, NY: Routledge.

Worthington, E. L., Jr., Hook, J. N., Davis, D. E., \& McDaniel, M. A. (2011). Religion and spirituality. In J. C. Norcross (Ed.), Psychotherapy relationships that work: Evidence-based responsiveness (2nd ed., pp. 402-422). New York, NY: Oxford University Press.

Worthington, E. L., Jr., \& Sandage, S. J. (2015). Forgiveness and spirituality in psychotherapy: A relational approach. Washington, DC: American Psychological Association. 


\section{APPENDIX}

\section{Worthington's Essential Resources on \\ Forgiveness, Hope, and Humility}

Brooks, D. (2015). The road to character. New York, NY: Random House.

Dickson, J. (2011). Humilitas: A lost key to life, love, and leadership. Grand Rapids, MI: Zondervan.

Enright, R. D., \& Fitzgibbons, R. P. (2014). Forgiveness therapy: An empirical guide for resolving anger and restoring hope. Washington, DC: American Psychological Association.

McCullough, M. E. (2008). Beyond revenge: The evolution of the forgiveness instinct. San Francisco, CA: Jossey-Bass.

Ripley, J. S., \& Worthington, E. L., Jr. (2014). Couple therapy: A new hope-focused approach. Downers Grove, IL: InterVarsity Press.

Snyder, C. R. (1994). The psychology of hope. New York, NY: Free Press.

Worthington, E. L., Jr. (2003). Forgiving and reconciling: Bridges to wholeness and hope. Downers Grove, IL: InterVarsity Press.

Worthington, E. L., Jr. (2006). Forgiveness and reconciliation: Theory and application. New York, NY: Brunner/Routledge.

Worthington, E. L., Jr. (2013). Moving forward: Six steps to forgiving yourself and breaking free from the past. Colorado Springs, CO: WaterBrook/Multnomah.

Worthington, E. L., Jr., \& Sandage, S. J. (2015). Forgiveness and spirituality in psychotherapy: A relational approach. Washington, DC: American Psychological Association. 